ENGINEERING CHANGE NOTICE

Page 1 of 3 $\triangle \mathrm{DM} \quad \square \mathrm{FM}$

$\square \mathrm{TM}$ 1a. ECN 727006 R 0

1b. Proj. ECN N/A - $\quad-\quad R$

\begin{tabular}{|c|c|c|c|c|c|}
\hline $\begin{array}{l}\text { 2. Simple Modification } \\
\square \text { Yes } \square \text { No }\end{array}$ & $\begin{array}{l}\text { 3. Design Inputs - Fo } \\
\text { required for Simple Mo }\end{array}$ & $\begin{array}{l}\text { full ECNs, r } \\
\text { ifications) }\end{array}$ & inforn & ration on the ECN-1 Form (not & $\begin{array}{l}\text { 4. Date } \\
12 / 09 / 2009\end{array}$ \\
\hline $\begin{array}{l}\text { 5. Originator's Name, Organiz } \\
\text { DJ Powers, System Enginee } \\
\text { R2-58, 373-9621 }\end{array}$ & $\begin{array}{l}\text { n, MSIN, \& Phone No. } \\
\text { and Support, }\end{array}$ & $\begin{array}{l}\text { 6. PrHA Nu } \\
\text { No. } 01158 \\
\text { R - O }\end{array}$ & N/A & $\begin{array}{r}\text { 7. USQ Number } \\
\text { No.T. O9-117i -DR-2 } \\
\square \text { N/A }\end{array}$ & $\begin{array}{l}\text { 8. Related ECNs } \\
\text { N/A }\end{array}$ \\
\hline $\begin{array}{l}\text { 9. Title } \\
\text { Update to Freight Container }\end{array}$ & ing Standard & Bldg. / Faci & & $\begin{array}{l}\text { 11. Equipment / Component ID } \\
\text { N/A }\end{array}$ & $\begin{array}{l}\text { 12. Approval Designator } \\
\text { N/A }\end{array}$ \\
\hline $\begin{array}{l}\text { 13. Engineering Documents/L } \\
\text { RPP- } 40736 \text {, Freight Contai }\end{array}$ & $\begin{array}{l}\text { vings to be Changed } \\
\text { Lifting Standard, } R\end{array}$ & $\begin{array}{l}\text { Sheet \& } \\
0\end{array}$ & S.) & $\begin{array}{l}\text { 14. Safety Designation } \\
\square \text { sc } \square \text { ss } \square \text { Gs } \square \text { N/A }\end{array}$ & $\begin{array}{l}\text { 15. Expedited/Off-Shift } \\
\text { ECN? } \\
\qquad \text { Yes } \square \text { No }\end{array}$ \\
\hline $\begin{array}{l}\text { 16a. Work Package Number } \\
\text { N/A }\end{array}$ & $\begin{array}{l}\text { 16b. Modification Wor } \\
\text { N/A }\end{array}$ & Completed & $\begin{array}{l}16 c . \\
\text { N/A }\end{array}$ & Restored to Original Status (TM) & $\begin{array}{l}\text { 17. Fabrication Support } \\
\text { ECN? } \\
\qquad \square \text { Yes } \square \text { No }\end{array}$ \\
\hline & Responsible Eng & / Date & & Date & \\
\hline
\end{tabular}

18. Description of the Change (Use ECN Continuation pages as needed)

RPP-40736, has been updated with editorial corrections. As well as RPP-40736 has had reference formatting changes to keep reference citing standards in order.

19. Justification of the Change (Use ECN Continuation pages as needed) Engineering Rework $\square$ Yes $\square$ No Training Impact $\square$ Yes $\bigotimes$ No Existing Test Program Worksheet (TWP): $\square$, Work is TP-3 $\square$, Test Program providing new TPW $\square$ The changes within RPP-40736 will allow the document better reading comprehension. Also the changes will be correcting minor editorial errors.
20. ECN Category

$\bigotimes$ Direct Revision

$\square$ Supplemental

$\square$ Void/Cancel

ECN Type

$\square$ Supersedure

$\square$ Revision

\begin{tabular}{|l|l|l|l|}
\hline 21. Distribution & MSIN & Name & MSIN \\
\hline Name & R2-58 & Rex Gillispie & S2-95 \\
\hline Daniel Powers & R2-95 & Randy Spaniel & S7-70 \\
\hline Mark Scott & R2-95 & Frederick Beard & A5-17 \\
\hline Thomas Mackey & S2-95 & & \\
\hline Craig Brewer & S2-95 & & \\
\hline Dana Morgan & T4-04 & & \\
\hline David McShane & S2-95 & & \\
\hline Michael Francis & & & \\
\hline
\end{tabular}




\section{ENGINEERING CHANGE NOTICE}

22. Revisions Planned (Include a brief description of the contents of each revision)

N/A

Note: All revisions shall have the approvals of the affected organizations as identified in block 12 "Approval Designator," on page 1 of this ECN.

23. Commercial Grade Item Dedication Numbers (associated with this design change)

N/A
24. Engineering Data Transmittal Numbers (associated with this design change, e.g., new drawings, new documents)

N/A

\section{Other Non Engineering (not in HDCS) documents that need to be modified due to this change}

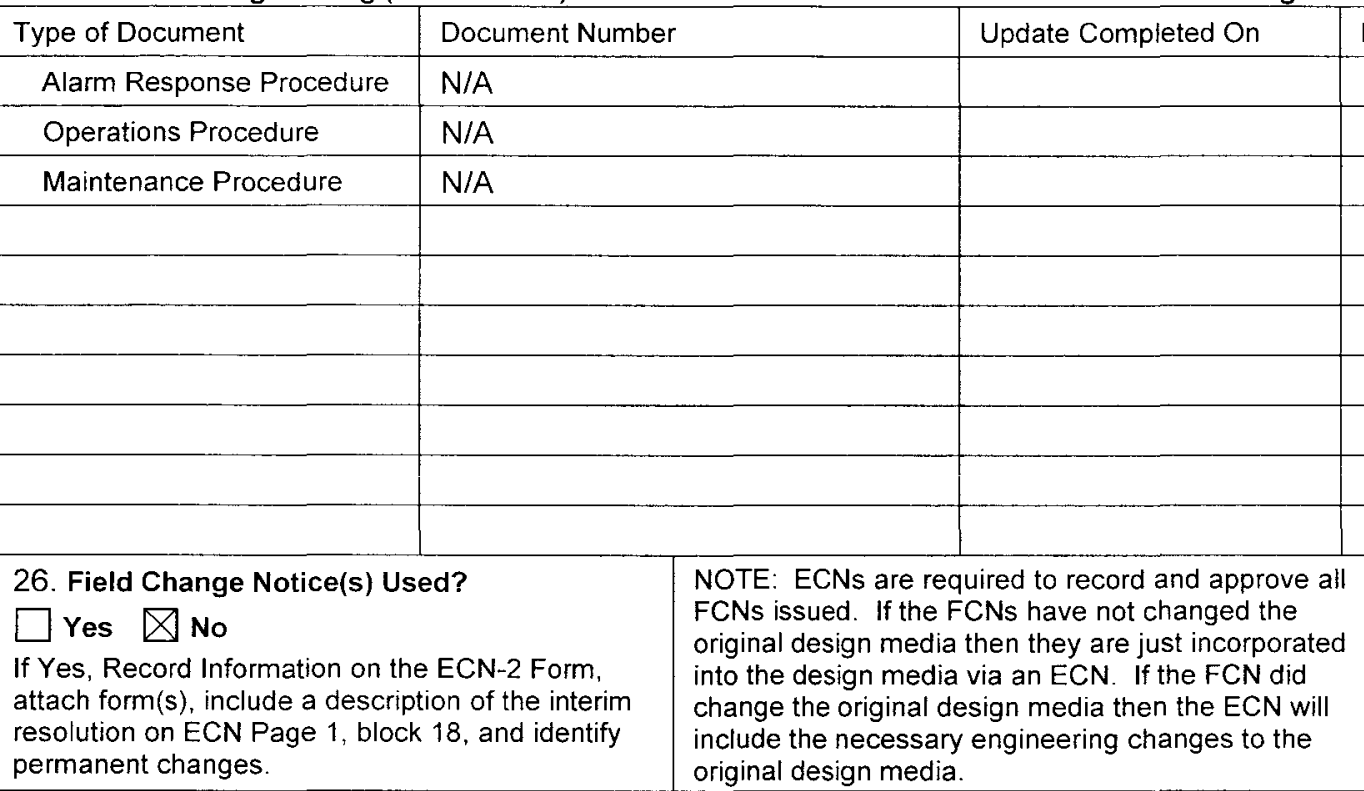
Responsible Engineer (print/sign and date)
28. Approvals
Facility/Project Signatures
Date
A/E Signatures

Resp. Engineer Daniel Powers

Quality Assurance

IS\&H Engineer

Project Engineer

NS\&L Engineer

Quality Assurance

Environ. Engineer

Engineering Checker

Other

Safety

27. Design Verification Required?

$\square$ Yes $\bigotimes$ No

If Yes, as a minimum attach the one page checklist from TFC-ENGDESIGN-P-17

\section{Other}

Other

Other

Other

Other

\section{ADDITIONAL SIGNATURES}




\section{ENGINEERING CHANGE NOTICE} CONTINUATION SHEET

Page 3 of 3

Document/Drawing No. N/A

N/A 1a. ECN 727006 R 0

1b. Proj. ECN N/A -

R

Sheet N/A

Revision N/A

Note: An AutoCAD page may be used in place of this form (the header section items must be included on the AutoCAD page). 


\section{INFORMATION CLEARANCE REVIEW AND RELEASE APPROVAL}

\section{Part I: Background Information}

Title:

Freight Container Lifting Standard

Publish to OSTI? $\bigotimes$ Yes $\bigotimes$ No

Document Number: RPP-40736, Rev.

Information Category: $\begin{array}{lllll}\square & \text { Abstract } & \square & \text { Journal Article } & \square \text { Summary } \\ \square & \text { Internet } & \square & \text { Visual Aid } & \square \text { Software } \\ \square & \text { Full Paper } & \square & \text { Report } & \square \text { Other Hosting fig inas }\end{array}$

Author: DJ Powers, MA Scott, \& TC Mackey

Purpose of Document: To clarify the proper freight container handling techniques

\section{Part II: External/Public Presentation Information}

Conference Name: $\mathrm{N} / \mathrm{A}$

Sponsoring Organization(s):

Date of Conference:

Conference Location:

Will Material be Handed Out?

$\square$ Yes

$\square$ No Will Information be Published?

$\square$ Yes

No

(If Yes, attach copy of Conference

Part III: WRPS Document Originator Checklist

\begin{tabular}{|c|c|c|c|c|}
\hline Description & & Yes & $N / A$ & Signature \\
\hline Information Product meets requirements & in TFC-BSM-AD-C-01? & $\$$ & & \\
\hline $\begin{array}{l}\text { Document Release Criteria in TFC-ENG } \\
\text { (Attach checklist) }\end{array}$ & -DESIGN-C-25 completed? & $\mathbf{X}$ & & \\
\hline If product contains pictures, safety revie & w completed? & & $\neg$ & \\
\hline Part IV: WRPS Internal Reviel & & & & \\
\hline Function & Organization & & Date & Signature/Date \\
\hline 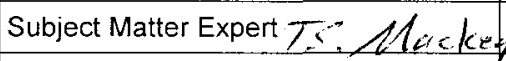 & contral Design & th & & \\
\hline Responsible Manager $E A N$ / sou & Centw| D $=5 \times 5 a$ & $-T h$ & & 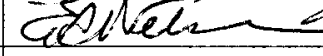 \\
\hline
\end{tabular}

Part V: IRM Clearance Services Review

Description

Document Contains Classified Information?

Document Contains Classified Information?

Document Contains Information Restricted by DOE Operational Security Guidelines?

Document is Subject to Release Restrictions?

If the answer is "Yes," please mark category at right and describe limitation or responsible organization below:

Additional Comments from Information Clearance Specialist Review?

Signature

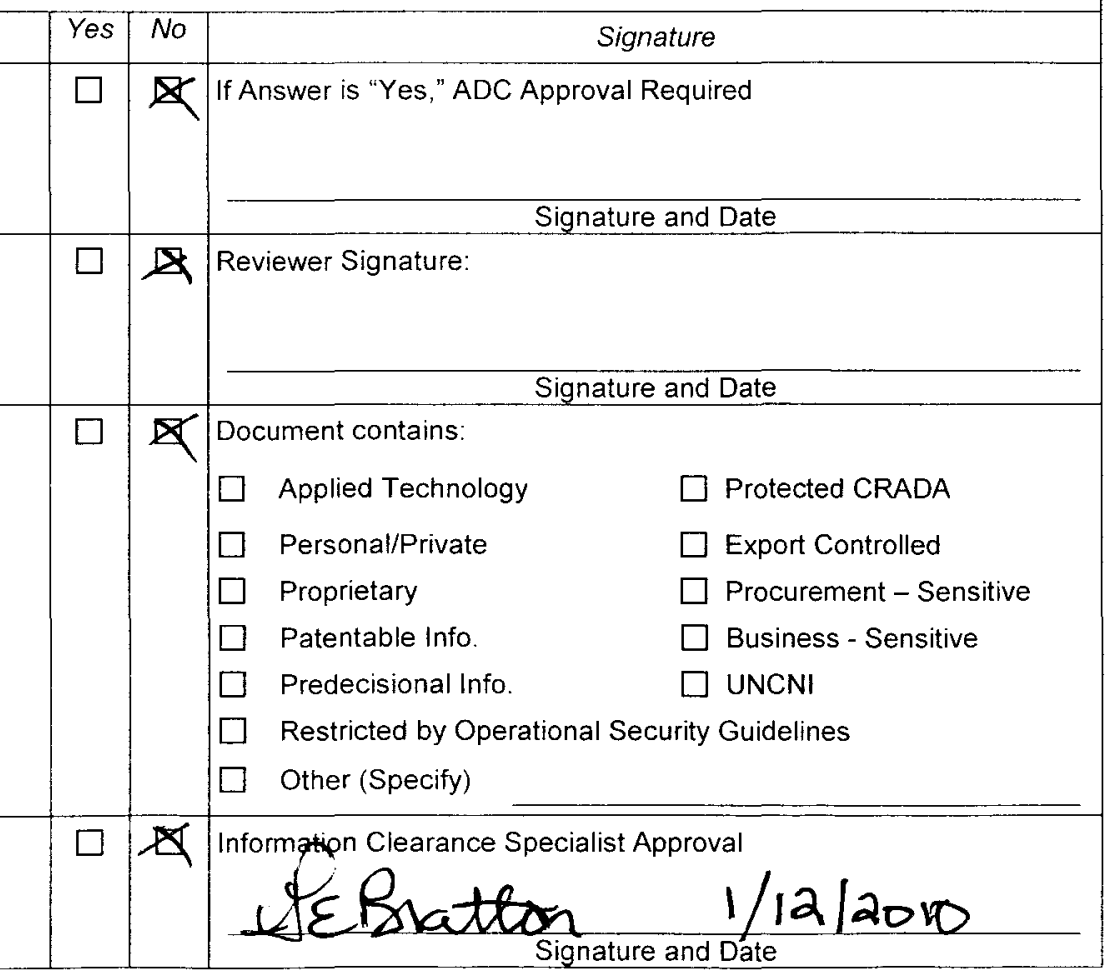

When IRM Clearance Review is Complete - Return to WRPS Originator for Final Signature Routing (Part VI) 


\section{INFORMATION CLEARANCE REVIEW AND RELEASE APPROVAL}

\section{Part VI: Final Review and Approvals}

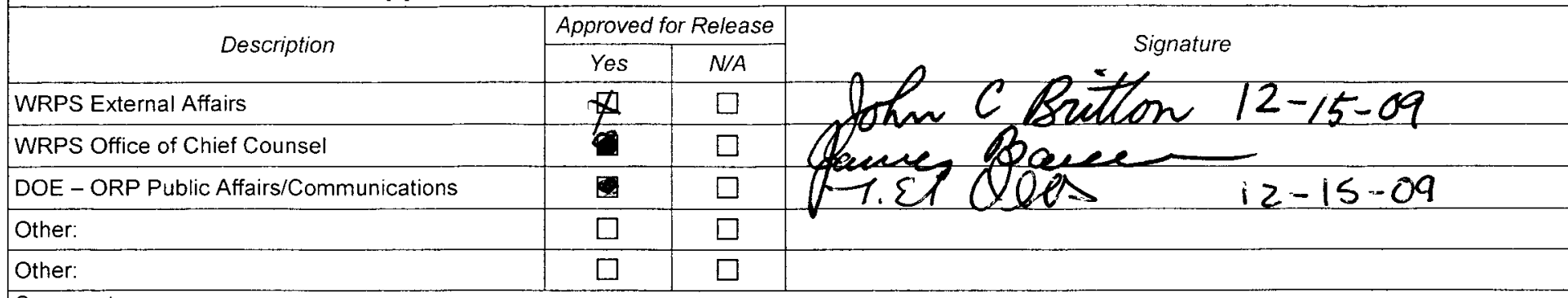

Comments:

Information Release Station

Was/ls Information Product Approved for Release? \&Yes $\square$ No

If Yes, what is the Level of Releaser? $\quad$ Kublic/Unrestricted $\square$ Other (Specify)

Date Information Product Stamped/Marked for Release: $01 / 62 / 2010$

Was/Is Information Product Transferred to OSTI? $\square$ Yes No

Forward Copies of Completed Form to WRPS Originator and WRPS CIO Office

\begin{tabular}{|l|c|c|c|}
\hline \multicolumn{1}{|c|}{ Description } & Yes & N/A & Signature \\
\hline WRPS Information Product & $\square$ & $\square$ & \\
\hline Conference Paper Guidelines & $\square$ & $\square$ & \\
\hline $\begin{array}{l}\text { Trademark/Copyright "Right to Use" Information } \\
\text { or Permission Documentation }\end{array}$ & $\square$ & $\square$ & \\
\hline WRPS Administrative Checklist & $\square$ & $\square$ & \\
\hline & $\square$ & $\square$ & \\
\hline & $\square$ & $\square$ & \\
\hline
\end{tabular}




\title{
Freight Container Lifting Standard
}

Daniel J. Powers, Mark A. Scott, and Thomas C. Mackey

Washington River Protection Solutions, LLC

Richland, WA 99352

U.S. Department of Energy Contract DE-AC27-08RV14800

\author{
EDT/ECN: 727006 Rev.0 UC: \\ Cost Center: \\ B\&R Code:

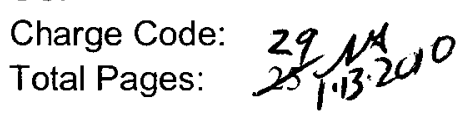

Key Words: Freight container, conex box, hoisting, lifting, handling, fork-lift, crane, rigging.

Abstract: This standard details the correct methods of lifting and handling Series 1 freight containers following ISO-3874 and ISO-1496.The changes within RPP-40736 will allow better reading comprehension, as well as correcting editorial errors.

TRADEMARK DISCLAIMER. Reference herein to any specific commercial product, process, or service by trade name, trademark, manufacturer, or otherwise, does not necessarily constitute or imply its endorsement, recommendation, or favoring by the United States Government or any agency thereof or its contractors or subcontractors.
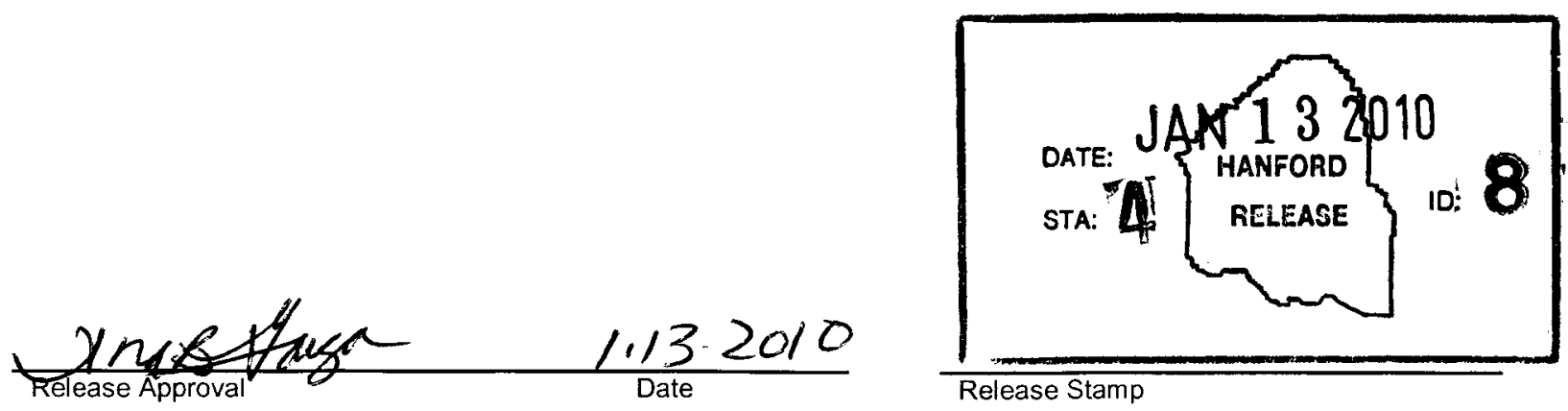

Approved For Public Release 


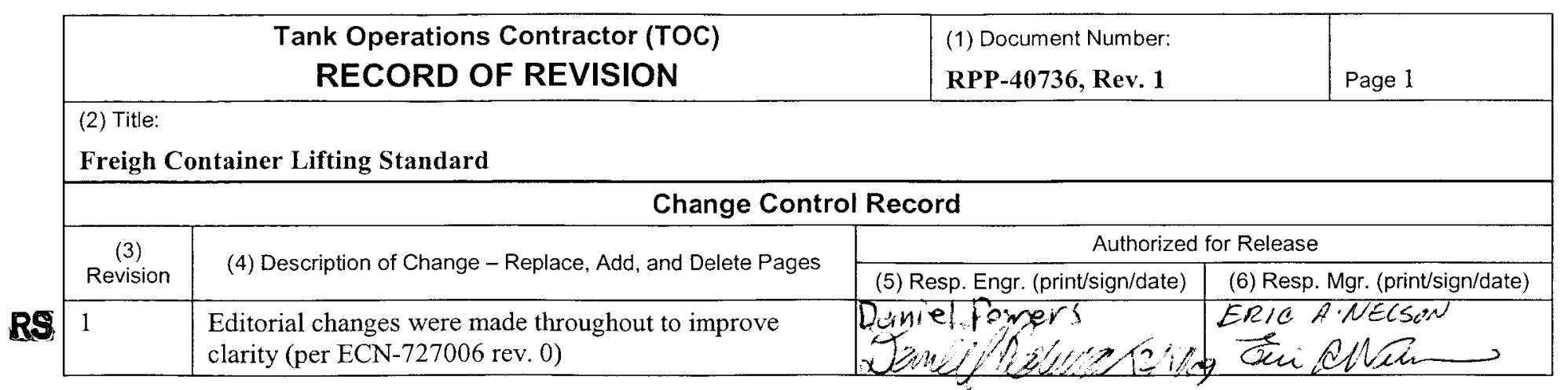

A-6003-835 (REV 2) 
RPP-40736

Revision 1

\section{Freight Container Lifting Standard}

Daniel J. Powers

Mark A. Scott

Thomas C. Mackey

Washington River Protection Solutions, LLC

Date Published

January 2010

Prepared for the U.S. Department of Energy

Office of River Protection

Contractor for the U.S. Department of Energy

Office of River Protection under Contract DE-AC27-08RV14800

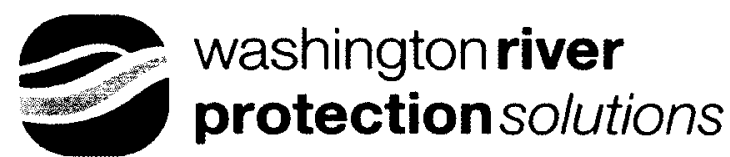

P.O. Box 850

Richland, Washington 99352 
TABLE OF CONTENTS

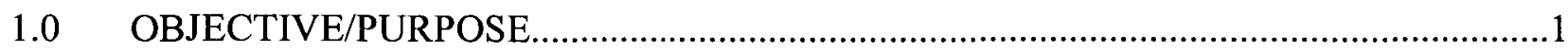

$2.0 \quad$ INTRODUCTION/BACKGROUND .................................................................

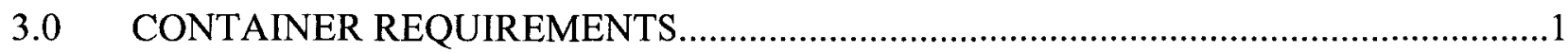

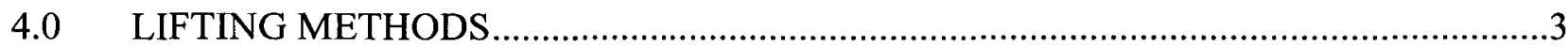

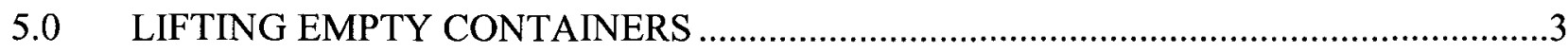

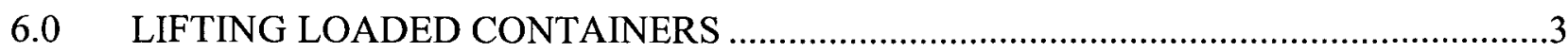

6.1 Top Lift Spreader Method .........................................................................4

6.2 Top Lift Sling Method ................................................................................

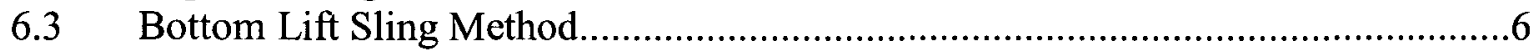

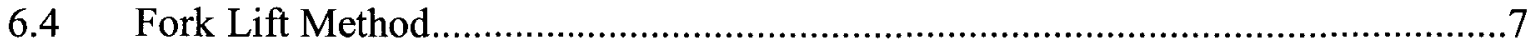

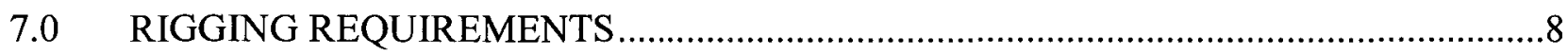

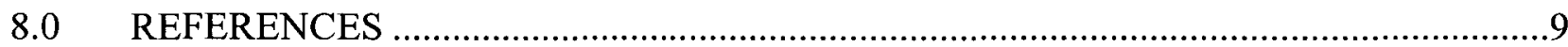

APPENDIX A-LIFT DESIGNATIONS ................................................................... A-1

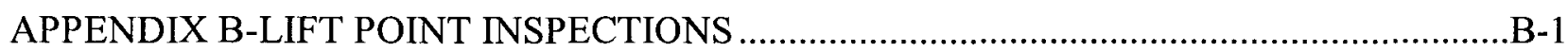

APPENDIX C-CLOSELY STACKED CONTAINERS .................................................

APPENDIX D-MODIFIED CONTAINERS ........................................................... D-1

APPENDIX E-MINIMUM SLING LENGTHS ............................................................ E-1

Figure 1. Top Lift Spreader Configuration .......................................................................

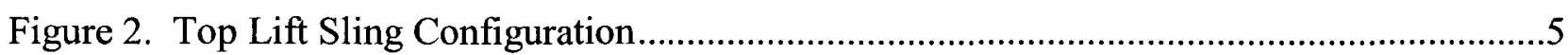

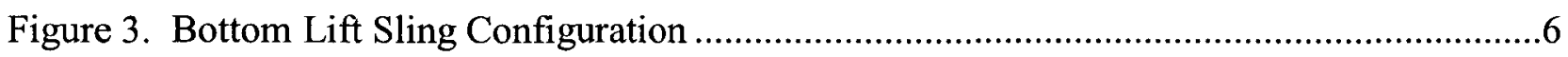

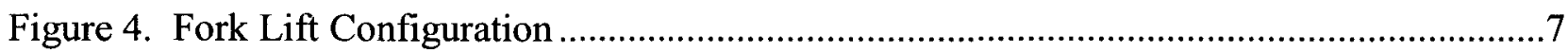

Figure 5. Example of one end of a box being lifted in order to slide sideways........................ -1

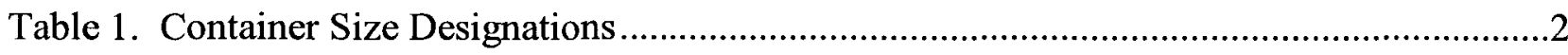

Table 2. Allowable Gross Weight of Containers ....................................................................2

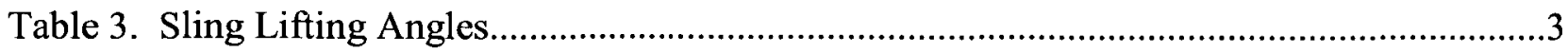

Table 4. Top Lift Spreader Acceptable Use Table ................................................................4

Table 5. Top Lift Sling Acceptable Use Table .......................................................................5

Table 6. Bottom Lift Sling Acceptable Use Table...................................................................6

Table 7. Fork Lift Acceptable Use Table............................................................................. 7 


\subsection{OBJECTIVE/PURPOSE}

This standard establishes the methods of lifting and handling freight containers (CONEX boxes) including the allowable lifting configurations, procedures, inspection and rigging requirements outside of maritime use. In order to safely lift any conex box, the type of conex box and proper rigging configuration must be determined prior to performing the lift evolution. Section 3.0 provides conex box measurements for the various types of boxes. Once the type of conex box is determined the lift configuration can be determined based on the load in the conex box. The type of conex box and the load of the conex box are used to determine the type of rigging configuration required to perform the lift.

\subsection{INTRODUCTION/BACKGROUND}

The maritime industry handling of the containers conforms to OSHA 29 CFR 1918, Safety and Health Regulations for Longshoring requirements. Questions were raised regarding the proper handling of freight containers for non-maritime applications and whether the maritime standards should be applied. Following a review of the various codes and standards related to container handling, there is primarily one International Standard, ISO 3874, Series 1 Freight Containers Handling and Securing that shows the proper lifting configurations for the proper handling of the freight containers. These configurations are for lifting containers that comply with the specification and testing for the minimum performance requirements for the manufacture of freight containers identified in ISO-1496-1 1990-08-15, Series 1 Freight ContainersSpecifications and Testing. The following lifting configurations and requirements for lifting freight containers will address the most common methods allowed to lift both empty and loaded containers. The lifting requirements follow the guidance of the OSHA 29 CFR 1918, ISO standards and a DOE-Idaho evaluation of container lifting points EDF-6285 (Reference 8). The EDF-6285 documents allowable loads for radioactive contaminated containers that comply with 49 CFR 173. The inspection of the container, inspection of the lift points, and the rigging hardware follow DOE-RL-92-36, the ASME B30 series of standards, this standard, and good industry practice-as applicable.

\subsection{CONTAINER REQUIREMENTS}

The Series 1 freight containers addressed in this standard should comply with ISO-1496. Other types of containers will be evaluated on a case-by-case basis. Table 1, below, shows the designations of the containers associated with nominal dimensions. The containers should be in good repair, with no significant corrosion or alterations to the container structure. If alterations to the container have been made since it was manufactured and put into service (doors, cut openings, vents) inspection should be completed by a qualified structural person to assure the alterations will not affect the structural integrity/capacity of the container when subjected to lifting loads. The corner fittings of the containers must meet the requirements of ISO 1161 1984-12-15, Series 1 Freight Containers - Corner Fittings - Specifications. The corner fittings should be in good repair with no visible signs of deformation of the holes (edges not straight and 
square) or excessive peening around the edges (rounded edges with metal deformed beyond the faces of the corner fittings).

The gross weight allowable from ISO 668 1995-12-15, Series 1 Freight Containers Classification, Dimensions and Ratings for the containers has a factor of safety of about 2 to 2.5 . To maintain the factor of 3 to yield requirements of 49CFR173.410 (Ref 5) for radioactive containers, use the load limits given by the calculation performed for the lift connections of freight containers containing radioactive materials at DOE-Idaho, EDF-6285, Evaluation of Cargo Container Lifting Fittings (Ref 8). This calculation reduced the allowable gross weight of the radioactive containers below the allowables of ISO 668 (see Table 2). Specific allowable gross weight of containers may be increased beyond Table 2 if documented by the manufacturer or by faceplate attached to the container. Contaminated containers must still be limited by the Table 2 values per EDF-6285.

Table 1. Container Size Designations

\begin{tabular}{|c|c|c|c|c|c|}
\hline \multicolumn{5}{|c|}{ Series 1 Freight Container Size Designations (ISO-3874) } \\
\hline Nominal Length & \multicolumn{5}{c|}{ External Height } \\
\hline $\mathrm{m}$ & $\mathrm{ft}$ & $<8 \mathrm{ft} 0$ in & $8 \mathrm{ft} \mathrm{0}$ in & $8 \mathrm{ft} 6 \mathrm{in}$ & $9 \mathrm{ft} 6 \mathrm{in}$ \\
\hline 12 & 40 & AX & A & AA & AAA \\
\hline 9 & 30 & BX & B & BB & BBB \\
\hline 6 & 20 & CX & C & CC & - \\
\hline 3 & 10 & DX & D & - & - \\
\hline \multicolumn{6}{|c}{ Note - All Units have a nominal width of $8 \mathrm{ft} \mathrm{0} \mathrm{in}$} \\
\hline
\end{tabular}

Note: containers designated "X" (e.g. DX or AX) are simply short, open-topped containers.

Table 2. Allowable Gross Weight of Containers

\begin{tabular}{|c|c|c|}
\hline \multicolumn{3}{|c|}{ Allowable Gross Weight of Containers } \\
\hline Container designation & Per ISO-668 (LBS) & Per EDF-6285 (Ref 8) \\
\hline AX, A, AA, AAA & 67200 & 44900 \\
\hline BX, B, BB, BBB & 56000 & 44900 \\
\hline CX, C, CC & 52900 & 44900 \\
\hline DX, D & 22400 & 22400 \\
\hline
\end{tabular}

Note: AX, A, AA and AAA are all the same length but they differ in height (see table 1). Likewise with $B, C$, and $D$ series containers. 


\subsection{LIFTING METHODS}

There are four basic lifting methods for freight contains. They are as follows: the Top Lift Spreader Method, the Top Lift Sling Method, the Bottom Lift Sling Method, and the Fork Lift Method. Any time a sling is used at an angle, it should follow the minimum angle requirements of Table 3 below. See specific lifting methods for more details. Appendix D lists minimum sling lengths to achieve the proper angle in different configurations.

Table 3. Sling Lifting Angles

\begin{tabular}{|c|c|}
\hline \multicolumn{2}{|c|}{ Sling Lifting Angles } \\
\hline Container Size Designation & Lifting Angle, $\alpha$, min \\
\hline AAA; AA; A; AX & $45^{\circ}$ \\
\hline BBB; BB; B; BX & $45^{\circ}$ \\
\hline CC; C; CX & $45^{\circ}$ \\
\hline D; DX & $60^{\circ}$ \\
\hline
\end{tabular}

\subsection{LIFTING EMPTY CONTAINERS}

Empty containers can be lifted by all four methods shown in Section 6: Top Lift Spreader, Top Lift Sling, Bottom Lift Sling and Fork Lift (Figures 1, 2, 3 and 4). Containers can be considered empty if the lifted weight is within 1000 pounds of the listed tare weight of the container. The minimum lifting angles are as shown in Table 3. Empty freight containers can be lifted from the top lift connections using hooks provided that the hooks are placed in an inward to outward direction as shown in Figure 2.

\subsection{LIFTING LOADED CONTAINERS}

All loaded containers can be lifted by the Top Lift Spreader Method or Bottom Lift Sling Method (Figures 1 and 3). Loaded CC, C, CX, D, and DX containers can be lifted with the Fork Lift Method, and loaded D and DX containers can be lifted with the Top Lift Sling Method. The corresponding tables (Tables 4 and 6) show which types of lifting methods can be used for the unloaded and loaded containers. The unacceptable methods are denoted by a shaded box in the tables associated with the lift methods. 


\section{RPP-40736, Rev. 1}

\subsection{TOP LIFT SPREADER METHOD}

The container is lifted by means of a spreader designed to lift containers by the top apertures of the four top corner fittings, the lifting forces being applied vertically. These spreaders have lifting devices specifically designed to connect to the top corner fittings of freight containers. They do not use normal hooks.

a. The lifting devices shall be properly engaged. Gathering devices shall impinge on corner fittings only.

b. The applicability of top lift spreaders is given in Table 4 .

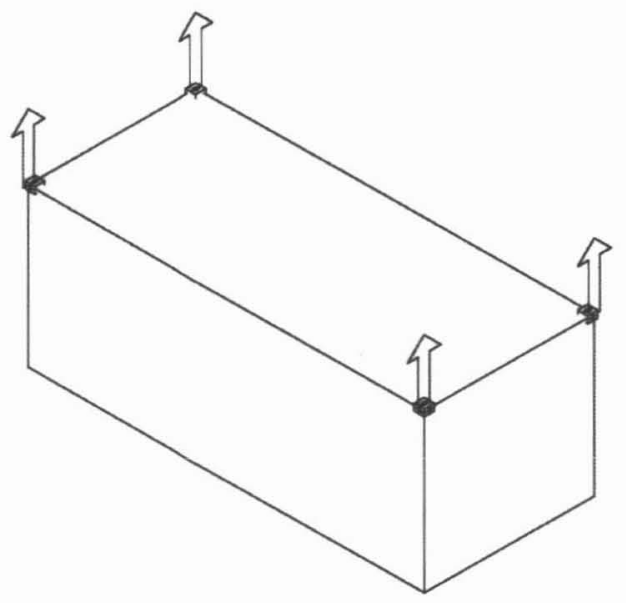

Figure 1. Top Lift Spreader Configuration

Table 4. Top Lift Spreader Acceptable Use Table

\begin{tabular}{|c|c|c|c|c|c|c|c|c|c|c|c|c|c|c|c|c|c|c|c|c|c|c|c|c|c|c|}
\hline \multicolumn{27}{|c|}{ TOP LIFT SPREADER } \\
\hline \multicolumn{13}{|c|}{ Empty Container } & \multirow{2}{*}{ Container Type } & \multirow{2}{*}{$\begin{array}{c}\text { ISO } \\
6346 \\
\text { Def }\end{array}$} & \multicolumn{12}{|c|}{ Loaded Container } \\
\hline AAA & AA & A & $\mathbf{A x}$ & Bв8 & B8 & B & $\mathrm{BX}$ & $\mathrm{CC}$ & $\mathrm{C}$ & $\mathrm{cx}$ & $\bar{D}$ & $\mathrm{DX}$ & & & AAA $A$ & \begin{tabular}{l|l}
$A A$ & $A$ \\
\end{tabular} & \begin{tabular}{l|l|l}
$A$ & $A$ \\
\end{tabular} & \begin{tabular}{l|l|l}
$A X$ & $B B B$ \\
\end{tabular} & BB & B & \begin{tabular}{|l|l}
$\mathrm{Bx}$ & $\mathrm{C}$ \\
\end{tabular} & $\mathrm{Cc}$ & \begin{tabular}{l|l}
$c$ & $C$ \\
\end{tabular} & $\mathrm{cx}$ & D & $\mathrm{DX}$ \\
\hline & & & n/a & & & & $\mathrm{n} / \mathrm{a}$ & & & n/a & & \begin{tabular}{l|l} 
n/a \\
\end{tabular} & General Purpose & GP, VH & & & & n/a & & & n/a & & & n/a & & n/a \\
\hline & & & & & & & & & & & & & Open Top & UT & & & & & & - & - & & & & & \\
\hline & & & & & & & & & & & & & $\begin{array}{l}\text { Bulk: non- } \\
\text { pressurized }\end{array}$ & Bu & & & & & & & & & & & & \\
\hline & & & $n / a$ & & & & $\mathrm{n} / \mathrm{a}$ & & & $n / a$ & & n/a & Thermal & $\begin{array}{l}\text { RE, RT, } \\
\text { RS }\end{array}$ & & & & n/a & & & n/a & & & n/a & & n/a \\
\hline $\mathrm{n} / \mathrm{a}$ & $\mathrm{n} / \mathrm{a}$ & n/a & & n/a & n/a & n/a & & \begin{tabular}{|l|l|l|}
$n$ & \\
\end{tabular} & n/a & & $\mathrm{n} / \mathrm{a}$ & & Platform & $\overline{P L}$ & \begin{tabular}{|l|l|} 
n/a & $n$ \\
\end{tabular} & \begin{tabular}{l|l}
$n / a$ & $n$ \\
\end{tabular} & \begin{tabular}{l|l} 
n/a & 11 \\
\end{tabular} & 1) $n / a$ & $\mathrm{n} / \mathrm{a}$ & $n / a \mid$ & 1) $[n$ & \begin{tabular}{l|l} 
n/a & $n$ \\
\end{tabular} & \begin{tabular}{l|l} 
n/a & 1 \\
\end{tabular} & 1) $[n$ & n/a & 1) \\
\hline
\end{tabular}

Allowed $\square$ Not allowed (or not applicable) 


\section{RPP-40736, Rev. 1}

\subsection{TOP LIFT SLING METHOD}

The Top Lift Sling method can only be used for handling empty containers (see Table 5) or loaded D or DX containers (10 ft long).

a. The container is lifted by all four top corner fittings with forces applied other than vertically.

b. Lifting devices shall be properly engaged. Hooks shall always be placed in an inward to outward direction along the length of the container (Figure 2b). These hooks should meet the criteria of ASME B30.10 (ref 11) and ISO 2308:1972 (ref 14).

c. The applicability of Top Lift Slings is given in Table 5.

d. For loaded containers, the lifted angle, $\alpha$, shown in Table 3, shall not be less than the minimum values shown in Table 3 or exceed the gross container weight of Table 2 . See Appendix E for minimum sling lengths to achieve the minimum angle.
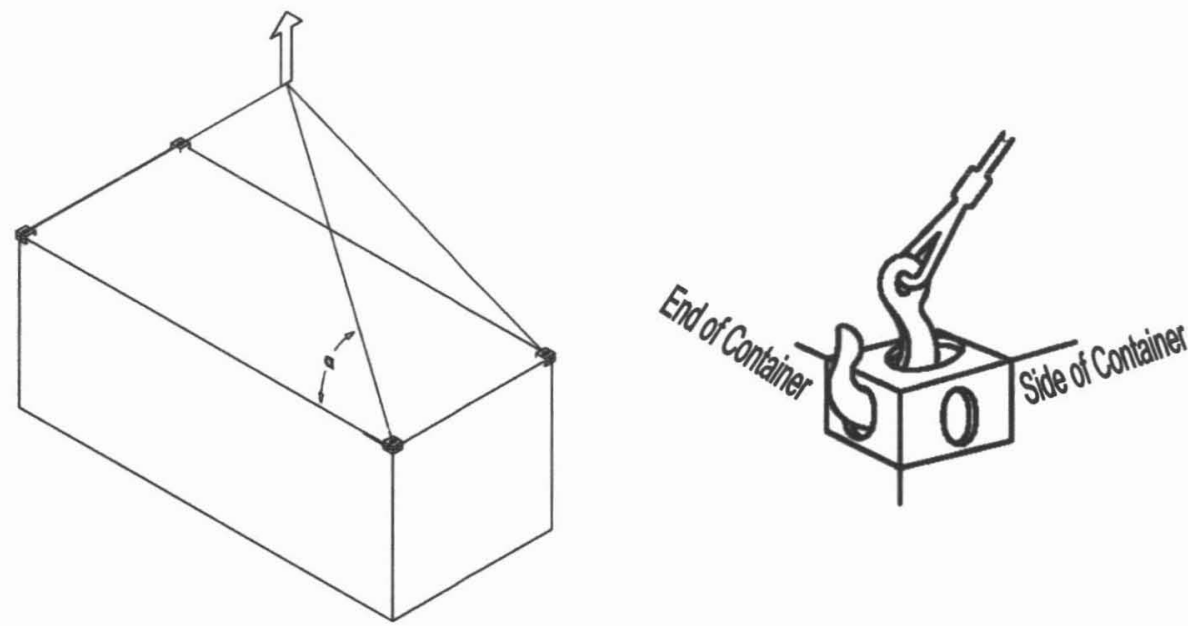

Figure 2. Top Lift Sling Configuration

Table 5. Top Lift Sling Acceptable Use Table

\begin{tabular}{|c|c|c|c|c|c|c|c|c|c|c|c|c|c|c|c|c|c|c|c|c|c|c|c|c|c|c|}
\hline \multicolumn{27}{|c|}{ TOP LIFT SLING } \\
\hline \multicolumn{13}{|c|}{ Empty Container } & \multirow{2}{*}{ Container Type } & \multirow{2}{*}{\begin{tabular}{|c|} 
ISO \\
6346 \\
Def \\
\end{tabular}} & \multicolumn{12}{|c|}{ Loaded Container } \\
\hline$\overline{\mathrm{AAA}}$ & AA & A & $A X$ & B8B & BB & B & $\mathrm{Bx}$ & $\mathrm{cc}$ & c & $c x$ & D & $\mathrm{Dx}$ & & & \begin{tabular}{|l|l|} 
AAA & AA \\
\end{tabular} & A & $A X$ & BBB & BB & B & $8 x$ & cc & c & cx & D & $\overline{D X}$ \\
\hline & & & n/a & & & & $\mathrm{n} / \mathrm{a} \mid$ & & & n/a & & $\mathrm{n} / \mathrm{a}$ & General Purpose & GP, VH & & & n/a & & & & n/a & & & n/a & 2) & n/a \\
\hline & & & & & & & & & & & & & Open Top & UT & & & & & & & & & & & 2) & 2) \\
\hline & & & & & & & & & & & & & $\begin{array}{l}\text { Bulk: non- } \\
\text { pressurized }\end{array}$ & BU & & & & & & & & & & & 2) & 2) \\
\hline 1) & 1) & 1) & $n / a|a|$ & 1) & 1) & 1) & $n / a$ & 1) & 1) & nia & 1) & $n / a \mid$ & Thermal & $\begin{array}{l}\text { RE, RT, } \\
\text { RS }\end{array}$ & & & $n / a \mid$ & & & & $n / a$ & & & $n / a$ & 2) & $\mathrm{n} / \mathrm{a}$ \\
\hline$n / a$ & nia & $n / a$ & & n/a & n/a & $n / a$ & L & n/a & $n / a$ & & $n / a$ & & Platform & $\mathbf{P L}$ & \begin{tabular}{|l|l|}
$|n / a|$ & $n / a$ \\
\end{tabular} & n/a & & & $n / a$ & n/a & & n/a & $n / a$ & & n/a & \\
\hline
\end{tabular}




\subsection{BOTTOM LIFT SLING METHOD}

The Bottom Lift Sling method of lifting can be used for empty and loaded containers. The container is lifted from the side of the four bottom corner fittings attached by slings to a spreader beam. The bottom sling attachment shall bear on the corner fittings only and should be such to exert lifting forces not more than 1.5 inches away from the outer face of the corner fittings (Figure 3b).

a. The lifting devices shall be properly engaged.

b. The applicability of the Bottom Lift Slings is given in Table 6 .

c. For loaded containers, the lifted angle, $\alpha$, shown in Figure 3, shall not be less than the minimum values shown in Table 3 or exceed the gross container weight of Table 2 . See Appendix E for minimum sling lengths to achieve the minimum angle.
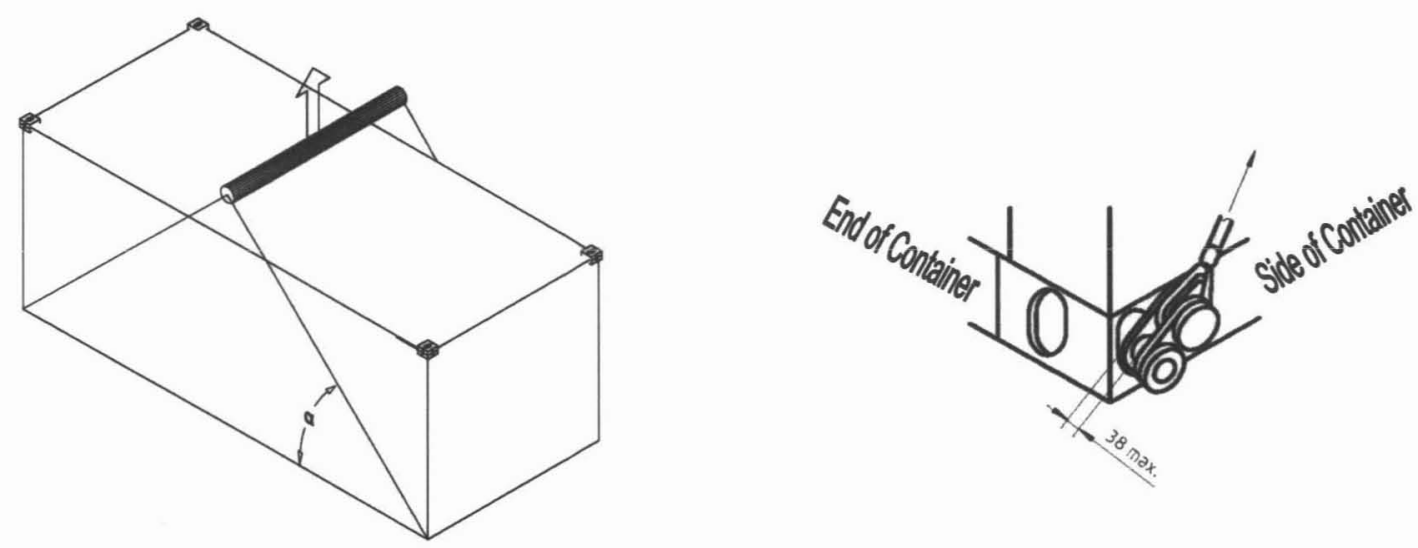

Figure 3. Bottom Lift Sling Configuration

Table 6. Bottom Lift Sling Acceptable Use Table

\begin{tabular}{|c|c|c|c|c|c|c|c|c|c|c|c|c|c|c|c|c|c|c|c|c|c|c|c|c|c|}
\hline \multicolumn{26}{|c|}{ BOTTOM LIFT SLING } \\
\hline \multicolumn{13}{|c|}{ Empty Container } & \multirow{2}{*}{ Container Type } & \multirow{2}{*}{$\begin{array}{c}\text { ISO } \\
6346 \\
\text { Def }\end{array}$} & \multicolumn{11}{|c|}{ Loaded Container } \\
\hline AAA & AA & $\mathbf{A}$ & $\mathrm{AX}$ & BвB & \begin{tabular}{|l|l|} 
BB \\
\end{tabular} & B & $\mathrm{Bx}$ & cc & c & $\mathrm{cx}$ & D & $\mathrm{Dx}$ & & & \begin{tabular}{l|l|l} 
AAA & A \\
\end{tabular} & \begin{tabular}{l|l} 
AA & A \\
\end{tabular} & \begin{tabular}{l|l|}
$\mathbf{A}$ & $\mathbf{A X}$ \\
\end{tabular} & \begin{tabular}{l|l}
$X$ & $B B E$ \\
\end{tabular} & \begin{tabular}{l|l|l|}
38 & BB \\
\end{tabular} & B & \begin{tabular}{l|l}
$\mathrm{Bx}$ & $\mathrm{C}$ \\
\end{tabular} & \begin{tabular}{|l|l}
$\mathrm{Cc}$ & $\mathrm{c}$ \\
\end{tabular} & \begin{tabular}{l|l}
$c$ & $c x$ \\
\end{tabular} & \begin{tabular}{l|l|}
$\mathrm{CX}$ & $\mathrm{D}$ \\
\end{tabular} & DX \\
\hline & & & $\mathrm{n} / \mathrm{a}$ & & & & n/a & & & $n / a \mid$ & & $n / a$ & General Purpose & GP, VH & & & & $1 / a$ & & & $\mathrm{n} / \mathrm{a} \mid$ & & & n/a & n/a \\
\hline & & & & & & & & & & & & & Open Top & UT & & & & & & & & & & & \\
\hline & & & & & & & & & & & & & $\begin{array}{l}\text { Bulk: non- } \\
\text { pressurized }\end{array}$ & Bu & 2) 2 & 2) 2 & 2) & 2) 2) & 2) & 2) & 2) 2 & 2) 2 & 2) 2) & 2) 2) & 2) \\
\hline 1) & 1) & 1) & $n / a$ & 1) & 1) & 1) & $n / a$ & 1) & 1) & $\mathrm{n} / \mathrm{a}$ & 1) & $n / a$ & Thermal & \begin{tabular}{|l|} 
RE, RT, \\
RS
\end{tabular} & 1) 2) 1 1) & 1) 2) 1) & ) 2) $n / 6$ & \begin{tabular}{l|l}
$1 / a$ & 1) 2
\end{tabular} & 2) 1) 2) | & 1) 2) $\mathrm{r}$ & \begin{tabular}{l|l} 
n/a & $1)$
\end{tabular} & 1) 2) (1) & 1) 2) $n / 2$ & la| 1) 2) & 2) $n / a$ \\
\hline $\mathrm{n} / \mathrm{a}$ & n/a & $n / a$ & & nnat & nal & n/a & & nla & nla & & \begin{tabular}{|l|l|} 
nnal \\
\end{tabular} & & Platform & PL & $n / a \mid n$ & \begin{tabular}{l|l}
$n / a$ & $n !$ \\
\end{tabular} & n/a & $\overline{n / a}$ & la & n/a & {$[n$} & \begin{tabular}{l|l|l|}
$n / a$ & $n !$ \\
\end{tabular} & $n / a$ & n/a & \\
\hline
\end{tabular}

Allowed

Not allowed (or not applicable) 


\subsection{FORK LIFT METHOD}

The container, if provided with fork-lift pockets as specified in ISO-1496-1 (shown in Figure 4), is lifted by means of forks. This method only applies to the $\mathrm{C}$ and $\mathrm{D}$ type containers (20 and 10 foot long containers) whether loaded or not (see table 7).

\section{a. Warning: Under no circumstances shall containers, with or without fork-lift pockets, be lifted by forks under the base of the container (as opposed to in fork-lift pockets).}

b. The forks should ideally extend the whole width of the container, but under no circumstances should they extend less than 6 feet or 72 inches.

c. When $1 \mathrm{CC}, 1 \mathrm{C}$ and $1 \mathrm{CX}$ containers are fitted with a second (inner) set of fork-lift pockets, these pockets shall be use for empty handling only.

d. The applicability of fork lifts is given in Table 7

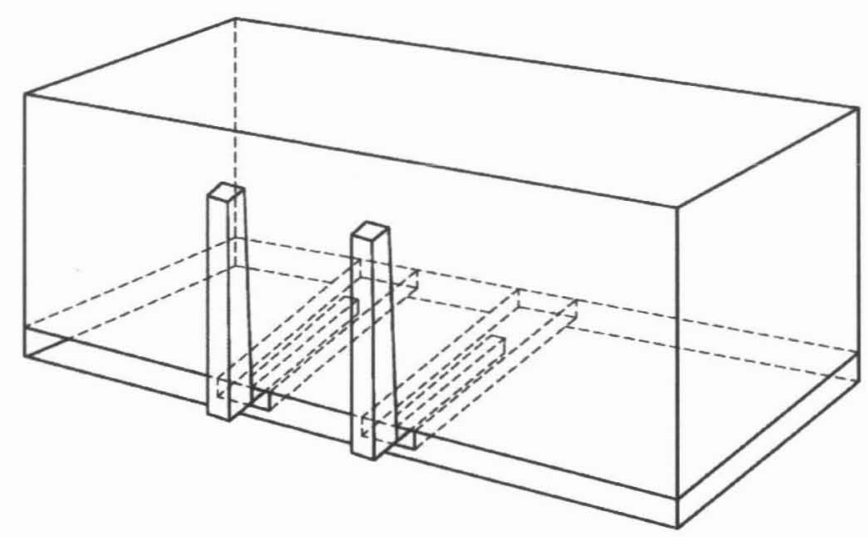

Figure 4. Fork Lift Configuration

Table 7. Fork Lift Acceptable Use Table

\begin{tabular}{|c|c|c|c|c|c|c|c|c|c|c|c|c|c|c|c|c|c|c|c|c|c|c|c|c|c|c|c|}
\hline \multicolumn{28}{|c|}{ FORK LIFTS } \\
\hline \multicolumn{13}{|c|}{ Empty Container } & \multirow[b]{2}{*}{ Container Type } & \multirow{2}{*}{$\begin{array}{l}\text { ISO } \\
6346\end{array}$} & \multicolumn{13}{|c|}{ Loaded Container } \\
\hline AAA & AA & A & $A X$ & BBB & BB & B & $\mathrm{Bx}$ & cc & c & $c x$ & D & Dx & & & AAA & AA & A & Ax & BBB & BB & B & $\mathrm{Bx}$ & cc & c & $c x$ & D & Dx \\
\hline & & & n/a & & & & n/a & & & n/a & & n/a & General Purpose & \begin{tabular}{|l|}
$\mathrm{UP}, \mathrm{VH}$ \\
\end{tabular} & & & & $n / a \mid$ & & & & $n / a \mid$ & & & $n / a$ & & $n / 6$ \\
\hline & & & & & & & & & & & & & Open Top & UT & & & & 2. & & & & 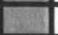 & 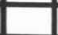 & & 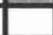 & & . \\
\hline & & & & & & & & & & & & & $\begin{array}{l}\text { Bulk: non- } \\
\text { pressurized }\end{array}$ & BU & & & & & & & & & 2) & 2) & 2) & 2) & 2) \\
\hline & & & $n / a$ & & & & $n / a$ & 1) & 1) & $n / a$ & 1) & $n / a$ & Thermal & $\begin{array}{l}\text { RE, RT, } \\
\text { RS }\end{array}$ & & & & $n / a$ & & & & $n / a$ & 2) & 2) & n/a & 2) & $\mathrm{n} / \mathrm{s}$ \\
\hline$n / a$ & $n / a$ & $n / a$ & & n/a & n/a & $n / a$ & & n/a & $\mathrm{n} / \mathrm{a}$ & & n/a & & Platform & $\overline{\mathrm{PL}}$ & \begin{tabular}{|l|}
$\mathrm{n} / \mathrm{a}$ \\
\end{tabular} & n/a & $\mathrm{n} / \mathrm{a}$ & $C_{0}$ & n/a & n/a & n/a & 3 & n/a & n/a & & $\mathrm{n} / \mathrm{a}$ & \\
\hline
\end{tabular}

Allowed $\square$ Not allowed (or not applicable) 


\subsection{RIGGING REQUIREMENTS}

The lifting device requirements for lifting the containers shall comply with the ASME B30.20 Below the Hook Lifting Devices as applicable and DOE-RL-92-36 for the below the hook lifting equipment. If an accurate reading for documentation or shipping purposes is required or if the estimated weight of the container is close to the maximum rated capacity of the container then a dynamometer shall be used to perform the lift. Assure that the maximum loads of the containers are not exceeded (see Table 3 ).

a. Care shall be taken to ensure that the equipment used is suitable for the load and is safely attached to the container and the container is free to be handled.

b. In the case of a single point lift, special attention should be paid to the risk of the container tilting due to eccentricity of the center of gravity. 


\section{RPP-40736, Rev. 1}

\subsection{REFERENCES}

49 CFR 173.410, Shippers - General Requirements for Shipments and Packaging, Subpart I - Class 7 (Radioactive) Materials, General Design Requirements.

ASME 30.10-2005, Hooks

ASME B30.20-2006, Below-the-Hook Lifting Devices

ASME B30.26-2004, Rigging Hardware

ASME B30.9-2006, Slings

ASME BTH-1-2005, Design of Below the Hook Lifting Devices

DOE-RL-92-36, Hanford Site Hoisting and Rigging Manual

EDF-6285, Evaluation of Cargo Container Lifting Fittings, Idaho Cleanup Project, USDOE by CH2M-WGIdaho, LLC.

ISO 1161 1984-12-15, Series 1 Freight Containers - Corner Fittings - Specifications.

ISO 1496-1 1990-08-15, Series 1 Freight Containers - Specification and Testing

ISO 2308:1972, Hooks for lifting freight containers of up to $30 \mathrm{t}$ capacity - Basic requirements.

ISO 3874, Series 1 Freight Containers - Handling and Securing

ISO 668 1995-12-15, Series 1 Freight Containers - Classification, Dimensions and ratings.

OSHA 29 CFR 1918, Safety and Health Regulations for Longshoring 
RPP-40736, Rev. 1

THIS PAGE INTENTIONALLY LEFT BLANK. 
RPP-40736, Rev. 1

\section{APPENDIX A}

Lift Designations

A-i 


\section{APPENDIX A-LIFT DESIGNATIONS}

\section{Lift Designations}

In order to plan for lifting freight containers (Conex boxes), the type of lift to be performed must first be determined. The lift will be designated as a "Normal", "Special", or "Critical" lift. Existing WRPS procedures and the DOE-RL-92-36 already address the requirements for planning and executing all lifts including Special and Critical lifts. For all types of lifts however, the type of container to be lifted must be determined. The type of container and the container capacity are usually posted on a metal placard inside the door of the container. If the placard information is not available, then the tables in this standard and the associated dimensions for each type of container can be used to determine the container type. The type determination and inspection of each container uses a graded approach.

\section{Lift Planning}

For Normal lifts, the planning process for lifting freight containers will normally involve at least the following:

1) Field Work Supervisor

2) (DL) designated leader performing the lift.

Special lifts may also require additional approval according to company procedures.

The Hanford Site Hoisting and Rigging Manual DOE-RL-92-36 requires critical lift signature approvals. Additional approvals may be required according to company procedures. 
RPP-40736, Rev. 1

THIS PAGE INTENTIONALLY LEFT BLANK.

A-2 
RPP-40736, Rev. 1

\section{APPENDIX B}

Lift Point Inspections

B-i 


\section{APPENDIX B-LIFT POINT INSPECTIONS}

For Normal lifts the inspection and evaluation of the container and lift points are performed by the Qualified Riggers performing the lift.

For Special and Critical lifts, the lift points and the containers will need to be evaluated by a Qualified Rigging Engineer.

All manufacturer-installed lift points shall be inspected and evaluated by a qualified person before use for cracks, deformation and excessive wear or damage. When questions arise regarding the use of manufacturer-installed lift points, the Qualified Rigging Engineer shall be consulted. 
RPP-40736, Rev. 1

THIS PAGE INTENTIONALLY LEFT BLANK. 
RPP-40736, Rev. 1

\section{APPENDIX C}

Closely Stacked Containers

C-i 


\section{APPENDIX C-CLOSELY STACKED CONTAINERS}

In some cases, Conex boxes may be closely stacked side by side. This may prevent lifters (corkies) from being installed on the sides of the bottom of the box. Thus, the Bottom Lift Sling Method cannot be used. In this case, the box may be lifted from the top lift points in order to relocate the box. If the box is loaded, the Top Lift Spreader method should be used.

Conex box spreaders, however, are expensive, heavy, and cannot be used if there are fans or other protrusions on the top of the container. Because of this, conex box spreaders are often unavailable or impractical. In these cases where conex box spreaders are unavailable or impractical and the box is loaded, the following approach should be followed:

- Install lifters (e.g. corkies) on the ends of the corner fittings on the bottom of one side of the box, and ensure that the lifters are properly engaged. The ends of the top corner fittings may not be used because they have a different sized and shaped hole.

- Connect slings to the lifting lugs and make sure they meet the requirements for minimum sling lifting angles given in Table 3 of this standard. Note: since corkies rely on the slings being angled to work properly, a spreader beam should not be used for this part of the operation; both slings should connect to one hook or shackle as shown in Figure 5. Lift the end of the box to a minimal height (ideally no more than a few inches off the ground) and shift it to the side. Use care not to side load the crane. The mobile crane operator should use the boom up method or the boom extension method when shifting one end of the container box.

- Set the box end down and repeat for the other side. This should create enough space between the conex boxes to install lifters on the sides of the box.

- Install lifters on the sides and use the bottom lift sling method to move the box.

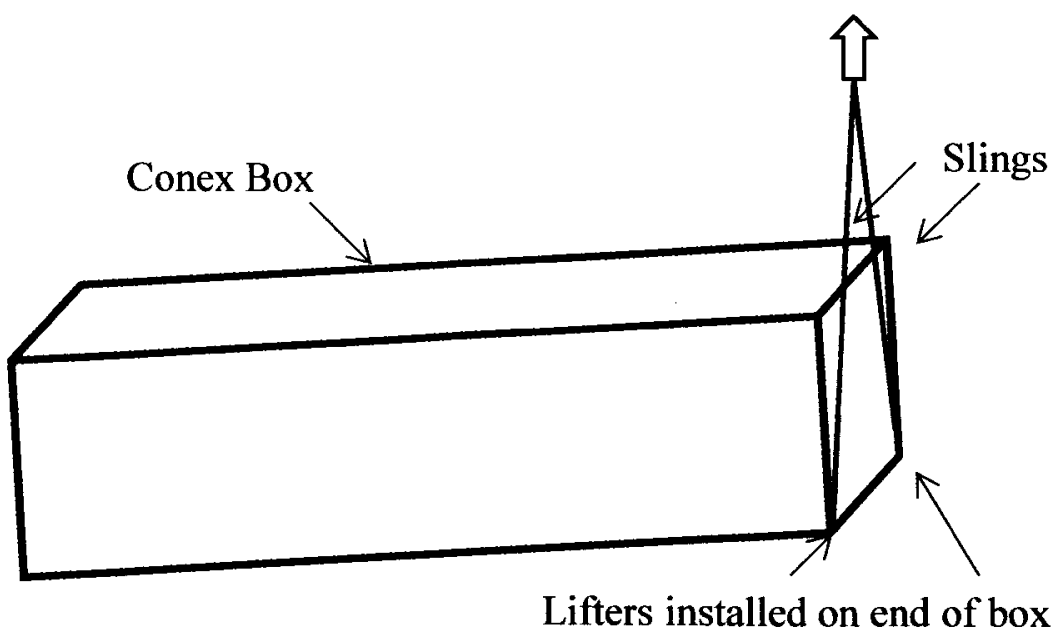

Figure 5. Example of one end of a box being lifted in order to slide sideways. 
RPP-40736, Rev. 1

THIS PAGE INTENTIONALLY LEFT BLANK.

C-2 
RPP-40736, Rev. 1

APPENDIX D

Modified Containers

D-i 


\section{APPENDIX D-MODIFIED CONTAINERS}

All Conex boxes will need to be inspected to determine if modifications have been made. If modifications have been made to the Conex box then it will need to be evaluated by a Qualified Rigging Engineer prior to performing the lift.

In all cases, an inspection of the Conex box is necessary to: 1) determine the type of Conex box and 2) to determine if there are any detrimental modifications that have been made to the box and 3) to evaluate the integrity of the lift points. If there are any questions regarding the integrity of the Conex box, contact the Civil/Structural Discipline Lead Engineer.

Some examples of modifications, as illustrated below, include adding roll up doors to the ends or to the sides of the box.

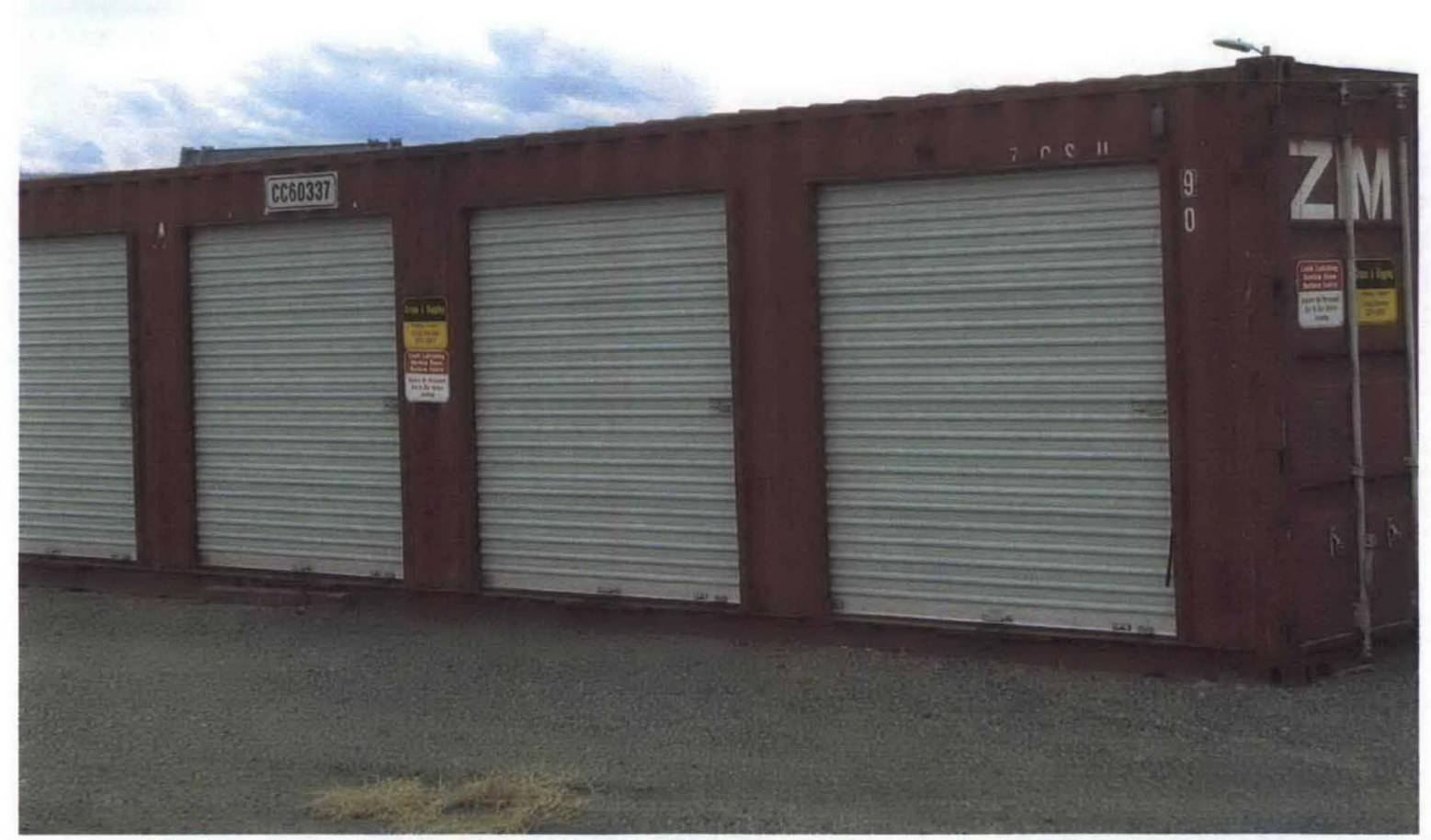

Doors added to the side of a Conex box. These may negatively impact the structural integrity of the box. 
RPP-40736, Rev. 1

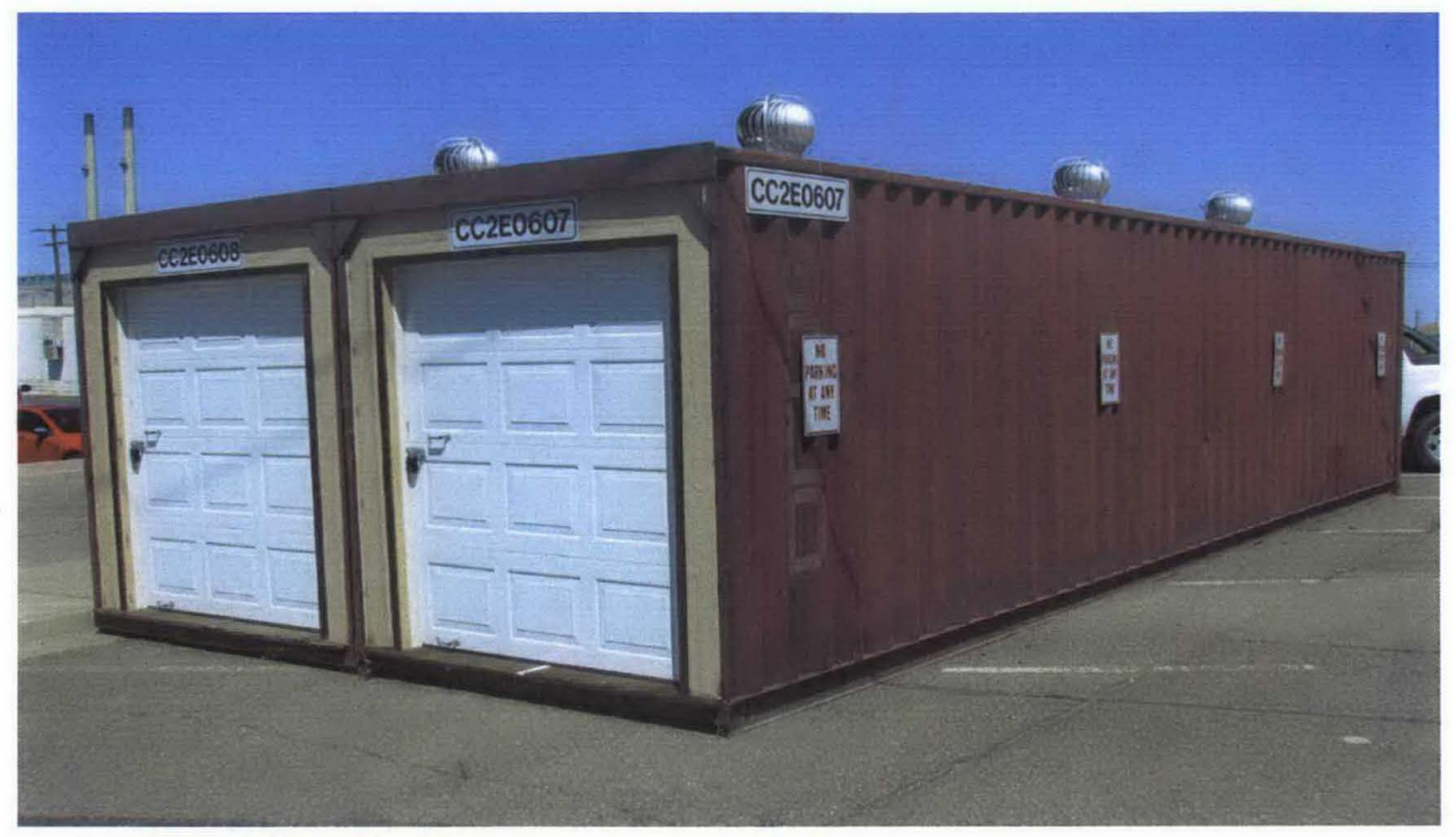

Doors added to the ends of two Conex boxes. These may also have a negative effect on the strength of the boxes. 
RPP-40736, Rev. 1

THIS PAGE INTENTIONALLY LEFT BLANK.

D-3 
RPP-40736, Rev. 1

\section{APPENDIX E}

Minimum Sling Lengths

E-i 
APPENDIX E-MINIMUM SLING LENGTHS

\begin{tabular}{|c|c|c|c|c|c|}
\hline \multicolumn{3}{|c|}{ TOP LIFT SLING METHOD } & \multicolumn{3}{|c|}{ BOTTOM LIFT SLING METHOD } \\
\hline $\begin{array}{l}\text { CONTAINER } \\
\text { TYPE }\end{array}$ & $\begin{array}{l}\text { DIMENSIONS } \\
(\mathbf{W} \times \mathbf{L})\end{array}$ & $\begin{array}{l}4 \text { WAY } \\
\text { BRIDLE } \\
\text { LENGTH }\end{array}$ & $\begin{array}{l}\text { CONTAINER } \\
\text { TYPE }\end{array}$ & $\begin{array}{l}\text { DIMENSIONS } \\
(\mathbf{W} \times \mathbf{X})\end{array}$ & $\begin{array}{l}2 \text { WAY } \\
\text { BRIDLE } \\
\text { LENGTH }\end{array}$ \\
\hline $\begin{array}{l}\mathbf{A X}, \mathbf{A}, \mathbf{A A}, \\
\mathbf{A A A}\end{array}$ & $8 \times 40$ & 30 & $\begin{array}{l}\mathbf{A X}, \mathbf{A}, \mathbf{A A}, \\
\mathbf{A A A}\end{array}$ & $8 \times 40$ & 30 \\
\hline $\begin{array}{l}\text { BX, B, BB, } \\
\text { BBBB }\end{array}$ & $8 \times 30$ & 24 & $\begin{array}{l}\text { BX, B, BB, } \\
\text { BBB }\end{array}$ & $8 \times 30$ & 24 \\
\hline $\mathrm{CX}, \mathrm{C}, \mathrm{CC}$ & $8 \times 20$ & $16^{\prime}$ & $\mathrm{CX}, \mathrm{C}, \mathrm{CC}$ & $8 \times 20$ & 16' \\
\hline $\mathbf{D X}, \mathbf{D}$ & $8 \times 10$ & 14' & $\mathbf{D X}, \mathbf{D}$ & $8 \times 10$ & 12' \\
\hline
\end{tabular}

Note 1: this table was made assuming the center of gravity is centered. Eccentric loads will require varying sling lengths or the addition of shackles.

Note 2: this table only gives sling lengths. Sling size (thickness) will be determined based on load and load placement characteristics and will vary case by case.

Note 3: Lifting lugs shall be properly engaged. Depending on the lugs used, this may require sling angle adjustment, but the angle shall not be below 45 degrees. 